\title{
Article \\ Study of Materials and Technique of Late Baroque Stucco Decorations: Baldassarre Fontana from Ticino to Czechia
}

\author{
Marta Caroselli ${ }^{1,2, *}$, Jan Válek ${ }^{3}{ }^{1}$, Jana Zapletalová ${ }^{2}{ }^{(0}$, Alberto Felici ${ }^{1,2}$, Dita Frankeová ${ }^{3}$, Petr Kozlovcev ${ }^{3}$, \\ Giovanni Nicoli ${ }^{1,2}$ and Giacinta Jean ${ }^{1}$ (D) \\ 1 Institute of Materials and Construction (IMC), University of Applied Sciences and Arts of Southern \\ Switzerland (SUPSI), CH-6850 Mendrisio, Switzerland; alberto.felici@supsi.ch (A.F.); \\ giovanni.nicoli@supsi.ch (G.N.); giacinta.jean@supsi.ch (G.J.) \\ 2 Faculty of Arts, Department of Art History, Palacký University, 77900 Olomouc, Czech Republic; \\ j.zapletalova@upol.cz \\ 3 Institute of Theoretical and Applied Mechanics, The Czech Academy of Sciences, 19000 Prague, \\ Czech Republic; valek@itam.cas.cz (J.V.); frankeova@itam.cas.cz (D.F.); itam@itam.cas.cz (P.K.) \\ * Correspondence: marta.caroselli@supsi.ch
}

check for updates

Citation: Caroselli, M.; Válek, J.; Zapletalová, J.; Felici, A.; Frankeová, D.; Kozlovcev, P.; Nicoli, G.; Jean, G. Study of Materials and Technique of Late Baroque Stucco Decorations: Baldassarre Fontana from Ticino to Czechia. Heritage 2021, 4, 1737-1753. https://doi.org/10.3390/ heritage 4030097

Academic Editor: Carlos Alves

Received: 14 June 2021

Accepted: 6 August 2021

Published: 11 August 2021

Publisher's Note: MDPI stays neutral with regard to jurisdictional claims in published maps and institutional affiliations.

Copyright: (c) 2021 by the authors. Licensee MDPI, Basel, Switzerland. This article is an open access article distributed under the terms and conditions of the Creative Commons Attribution (CC BY) license (https:// creativecommons.org/licenses/by/ $4.0 /)$.
Abstract: From the 16th to the 18th century, many artists and craftspeople coming from villages in the Italian-speaking part of Switzerland, well known for its stucco tradition, worked actively in Central Europe. Baldassarre Fontana (Chiasso 1661-1733) was one of them; after a period in Rome, he was active in Moravia and Poland. This contribution presents an analytical insight into stucco works in the Ticino canton and Czech lands in order to provide an understanding of how artistic and technical skills were transferred according to local traditions, materials, or other requirements found abroad. By comparing two works that Fontana realized in his homeland and two works that he realized in today's Czech Republic, the historic techniques used to make stucco are characterized, with an emphasis on technological aspects and materials. The detailed analyses provide information on materials and their production and processing methods in relation to the specific sites. They also reveal certain specific technological approaches which were common in all four cases that were studied. The most significant was the layered system of high-relief pieces, where the ground layer was made of lime-gypsum mortar and the finishing layer was pure air lime mortar. The construction of the finishing layer differed between the Czech and Swiss sites, suggesting some other influential factors.

Keywords: stucco decorations; gypsum; Mg lime; mortar analyses; stucco production technology

\section{Introduction}

The artists and craftspeople from the region of the Lombard-Ticino lakes-corresponding geographically to what is today Northern Lombardy (Italy) and Southern Ticino (Switzerland)-were highly regarded from the middle of the 16th to the beginning of the 18th century by patrons of the arts in many parts of Europe [1-3]. This fact demonstrates not only their capacity to work in teams in well-connected networks, but also a great ability to adapt to new environments. It can be inferred that the flexibility and versatility of these artists were applied not only to different cultural settings, regional customs, the requirements of patrons, different tastes, etc., but also to the use of local raw materials. Stucco artists, in particular, found themselves having to work with different geological contexts in various parts of Europe, or with products that differed in their quality and characteristics [4]. Therefore, they could not apply the same tried-and-tested formulae and approaches everywhere. On their journeys, they had to constantly adapt to create stucco decorations, using what was available locally and adjusting their modus operandi accordingly.

In this article, based on the example of the leading stucco artist Baldassarre Fontana (1661-1733), two different research teams have examined and compared the stucco works 
that he created in selected localities in Switzerland and today's Czech Republic. The selected sites serve the purpose of comparing Fontana's work from his home region and high-level commissions abroad. The chosen sites represent his work at different stages of his recognized career.

The aim was to verify how the stuccos differed in terms of composition, and if the variations in the raw materials forced him to apply different working techniques to realize the desired models. The technical specificity or materials used by Fontana have not yet been described in the published literature since only formal descriptions are available, and a further purpose of this paper is to provide such information.

\subsection{Baldassarre Fontana, a Stucco Artist in Ticino and Moravia}

Baldassarre Fontana was one of the most prominent stucco artists to come from the region of the Lombard-Ticino lakes [5-9]. The development of his artistic potential was fundamentally influenced by a period he spent in Rome, evidently close to his fellow countryman Ercolo Antonio Raggi (1624-1686) and other pupils and assistants of Bernini.

The first mention of Fontana in Central Europe was in 1688, when he was recorded as being in Moravia. He remained connected with that area for the rest of his life, and he created several dozen pieces of work there. In the 1690s and the early 18th century, in particular, he also travelled to present-day Poland, where he realized the stucco decoration in the church of St. Anne and the monastery church of St. Andrew in Kraków. His most successful works also include the decoration of the sala terrenas in the château in Kroměřǐz, the library of the Premonstratensian canonry in Hradisko, and the castle in Uherčice in the Czech Republic. In Central Europe Baldassarre Fontana was one of the most famous artists in his field, comparable to other figures of European stature, such as, for example, Santino Bussi (1664-1736).

\subsection{Case Studies}

Samples of his artworks were selected from four localities: two from the Ticino canton in Switzerland and two from Moravia in the Czech Republic. All the collected samples were analyzed in a laboratory. The two Moravian localities were chosen because of the recent restoration works, which facilitated detailed observations and scientific investigations. The two case studies analyzed in the Ticino canton are the only ones that have been attributed to Fontana in Switzerland so far. In both cases, however, there are no archival documents that certify with certainty the authorship of these stucco works, but the attributions that can be found in the literature have taken into consideration stylistic similarities to documented case studies [6-9]. The individual buildings are briefly described below, ordered according to the possible date of erection.

\subsubsection{Uherčice Castle, 1692-1696 (CZ)}

Donat Heissler of Heitersheim (1648-1696) commissioned Baldassarre Fontana and his assistants to decorate nine halls and the castle chapel in Uherčice, probably in the years 1692-1696 (until now the decoration has been dated 1705-1707, but by then Donat Heissler of Heitersheim was already dead) [10-12]. Although archive sources are not available to confirm which artist was responsible for the extensive stucco decoration or the date when it was created, we can quite certainly assume that they are the work of Fontana because of clear stylistic analogies with other works by this artist (Figure 1) [5-7].

The figurative bas-reliefs were realized with three different layers of mortar (two internal ground layers and a finishing layer) applied wet-on-wet in order to model all the layers together. The phytomorphic decorations under the arches, ribs, and garlands are rich in detail, reproducing their natural shape perfectly. The support was prepared with a binder-rich mortar, applied in different thicknesses on a case-by-case basis. Leaves and fruits were inserted directly into the fresh mortar or applied after setting with the use of metal nails as anchoring plugs. Figures and forms that stood out from the background contained reinforcement (Figure 2). The cherubs were probably made directly on-site, with 
their adhesion being reinforced with a metal nail. Around this nail, the ground layer is first applied as a draft of the final form. Afterwards, in order to model all the expressive details of their bodies and faces, the finishing was applied in a thick layer, between 1 and $5 \mathrm{~mm}$ in thickness.

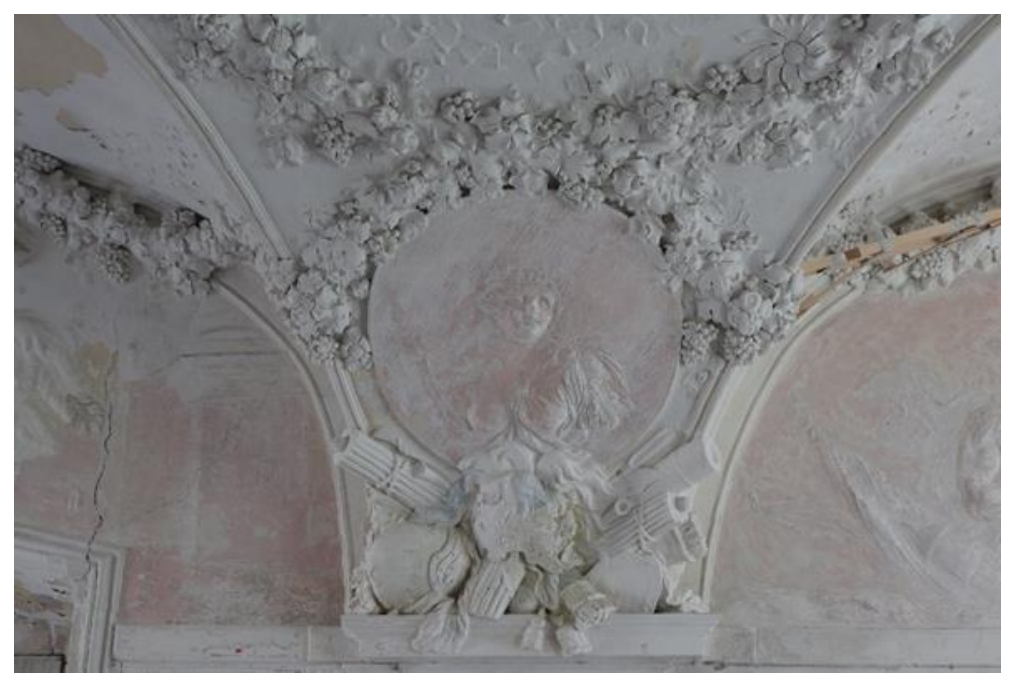

Figure 1. Heissler's study room in Uherčice Castle, image of a stucco relief before restoration works.

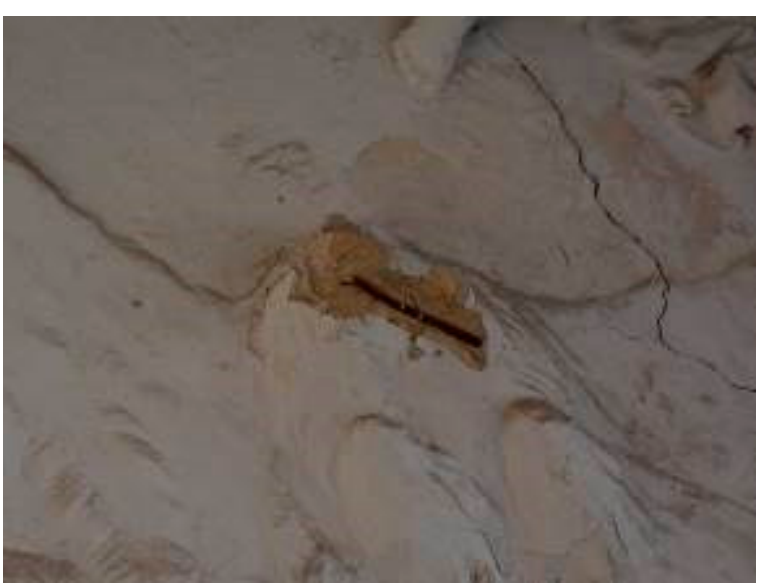

(a)

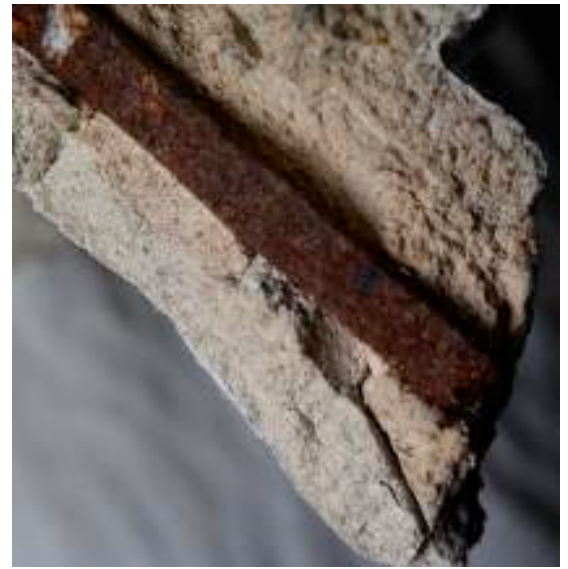

(b)

Figure 2. Heissler's study room: (a) broken eagle's head; (b) the close-up image shows the internal structure. The ground mortar (sample JUHE 002) is wrapped around a squared iron bar app. $10 \mathrm{~mm} \times 6 \mathrm{~mm}$ across and finished with a stucco finishing layer (sample SUHE 002).

From visual observation, it can be seen that the mortar layers have aggregates with decreasing grain size towards the surface. For some bas-reliefs, the finishing layer is very thin, possibly only a limewash, applied to make the color uniform and compact the surface.

\subsubsection{Church of San Giovanni Evangelista, Morbio Superiore (CH), 1701}

The stucco decoration in the sacristy of the church, originally thought to be the work of Agostino Silva, has been attributed to Fontana by Mariusz Karpowicz on the basis of stylistic analogies [6]. Although this decoration displays the use of similar motifs to those in Fontana's stucco works in, for example, Kraków, Velehrad, and Uherčice, it has yet to be proved by further studies similar to this one as to whether it is the work of Fontana himself or one of his close and highly skilled assistants.

The decoration of the vault is made of ornamental elements, with thin and not very pronounced modeling. Unfortunately, the presence of a thick layer of limewash and 
numerous added re-paintings do not allow the precise identification of details that would facilitate the understanding of the technical procedures. The supporting structures are made of bricks or stones, on top of which mortar is modeled in relatively thin layers with rather fine aggregates. The finishing layer reaches a thickness of up to $1.5 \mathrm{~cm}$. Because of the very slight projection of the decorations, no anchoring was required, with the exception of a single nail in the center of the ceiling rose.

\subsubsection{Casa Cantoni, Cabbio (CH), Early 18th Century}

The stucco work in Casa Cantoni in Cabbio has been attributed to Fontana by Mariusz Karpowicz on the basis of stylistic analogies [6]. It has traditionally been dated to the early 18th century $[13,14]$.

The stucco fireplace is made of two superimposed layers of mortar, the ground layer containing sand (with a grain size of up to 2-3 $\mathrm{mm}$ ) and the finishing layer composed of fat lime, with a thickness of about 1-3 mm. In particular, in the two lateral puttini of the chimney, it is possible to see an internal wooden structure. It is a fine cylinder of wood, apparently a twig, whose light bark has not been removed, around which the amber-colored body mortar has been applied in a single layer (Figure 3). The finishing layer is about $1-2 \mathrm{~mm}$ thick and is smooth and well-polished. A survey with a pacometer confirmed the very limited use of iron elements, probably just a few nails with which the more projecting elements were anchored to the wall.

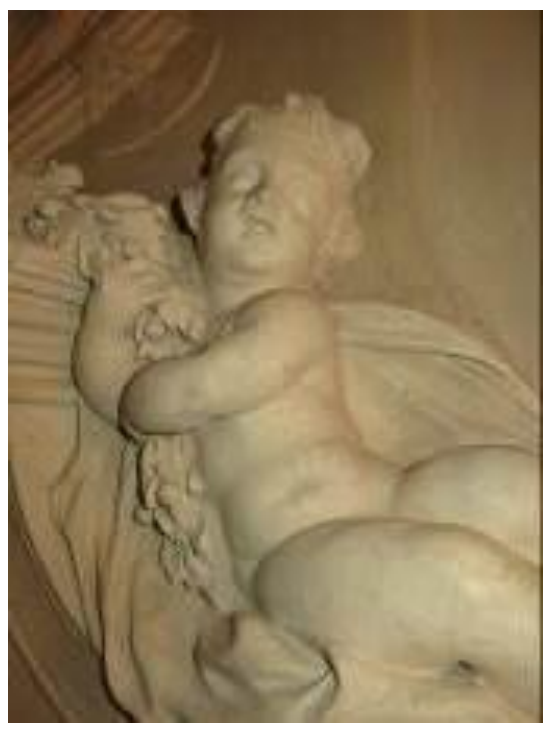

(a)

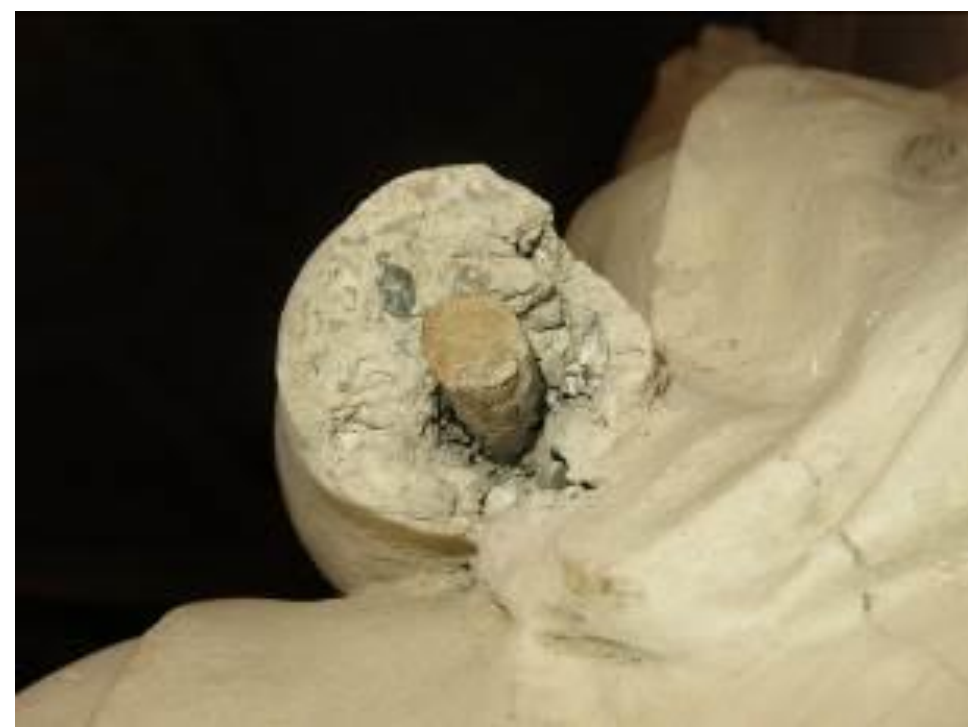

(b)

Figure 3. Stucco decoration of Casa Cantoni in Cabbio: (a) detail of a putto stucco decoration of the fireplace; (b) the close-up image shows the internal structure. It is made of two superimposed layers of mortar, a ground layer with coarse aggregate and a finishing layer, a few $\mathrm{mm}$ in thickness. Inside, the internal wooden structure is visible.

\subsubsection{The Holy Hill Church near Olomouc (CZ), 1722-1731}

The stucco decoration of the basilica on the Holy Hill near Olomouc is definitely one of the late works of Fontana and his workshop, being well documented [5,6]. A number of archive documents relating to this work are available, including the contract, on the basis of which the stuccoes can be dated to the years 1722-1731. Because of the client's wish to give the original stucco decoration from the 1670s a modern look, Fontana enriched the older stucco on the walls and vaults with new figures. In many places throughout the basilica, he designed new stucco figures of angels and created new altars in the side chapels; in particular, he decorated the main altar with the monumental figure of God the Father and 
angels (Figure 4). The Premonstratensians desired to give the interior an exclusive look, and therefore many of the stuccoes were inlaid with gold.

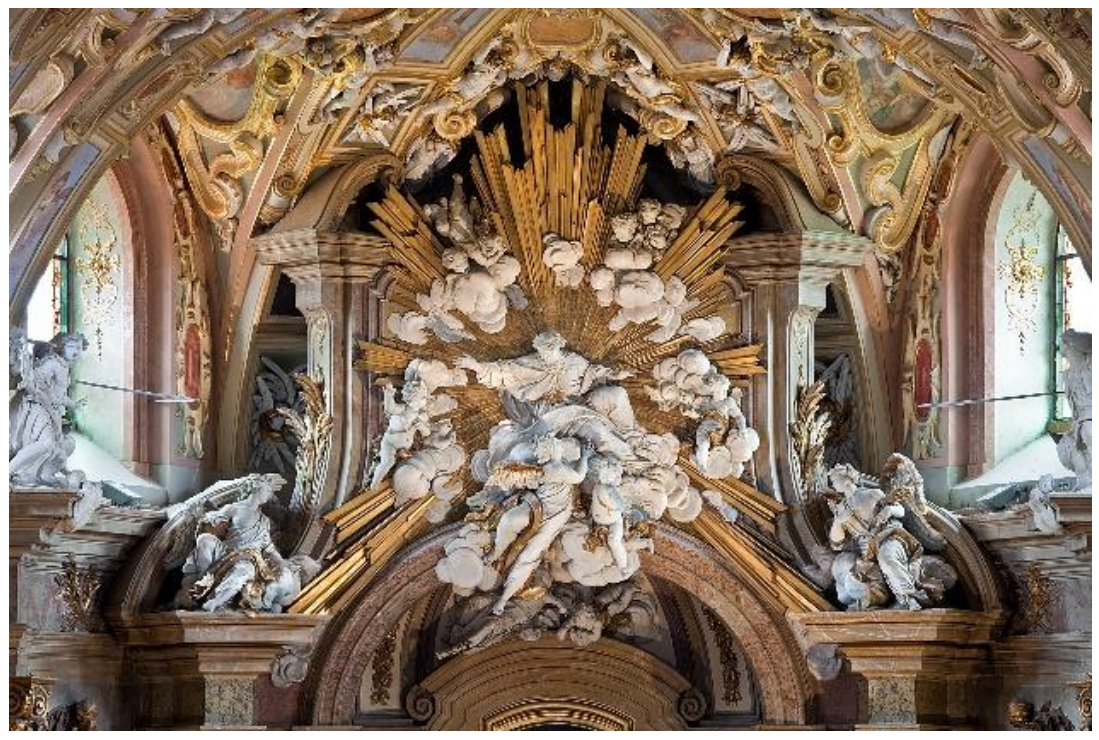

Figure 4. Stucco decoration in the Holy Hill near Olomouc, image before restoration works.

\section{Materials and Methods}

The comparison of the respective production technologies and materials used was carried out on the basis of on-site technical observations and scientific analyses conducted on stucco samples collected from all the mentioned case studies (Table 1). The aforementioned aspects have been discussed within the context of the information gained through research into historical documentation and archive materials.

Table 1. List and description of samples. For each sample, the stucco element from which it was taken is indicated as is the position and the building of origin, with the specification of whether it is a Swiss or Czech site. The last column lists the analyses that were performed.

\begin{tabular}{|c|c|c|c|c|}
\hline Sample Id & Element & Position & Case Study & Analyses \\
\hline MSP_SG 01 & Stucco layer & $\begin{array}{c}\text { Bas-relief vault } \\
\text { decoration }\end{array}$ & Church of San Giovanni Evangelista $(\mathrm{CH})$ & PLM, FT-IR \\
\hline MSP_SG 02 & Ground mortar & Cornice & Church of San Giovanni Evangelista $(\mathrm{CH})$ & PLM, FT-IR \\
\hline MSP_SG 03 & Stucco layer & $\begin{array}{c}\text { Bas-relief vault } \\
\text { decoration }\end{array}$ & Church of San Giovanni Evangelista $(\mathrm{CH})$ & PLM, FT-IR \\
\hline $\begin{array}{c}\text { MSP_SG 07, MSP_SG } \\
\text { 08, MSP_SG 09, } \\
\text { MSP_SG } 10\end{array}$ & Stucco layer & $\begin{array}{l}\text { Bas-relief vault } \\
\text { decoration }\end{array}$ & Church of San Giovanni Evangelista $(\mathrm{CH})$ & MALDI-TOF \\
\hline CB_01 & Ground mortar & Putto, right foot & Casa Cantoni, Cabbio $(\mathrm{CH})$ & PLM, FT-IR \\
\hline CB_02 & Stucco layer & Putto, right foot & Casa Cantoni, Cabbio $(\mathrm{CH})$ & PLM, FT-IR \\
\hline CB_03 & Stucco layer & Leaf decoration & Casa Cantoni, Cabbio $(\mathrm{CH})$ & PLM, FT-IR \\
\hline CB_04 & Stucco layer & Leaf decoration & Casa Cantoni, Cabbio $(\mathrm{CH})$ & PLM, FT-IR \\
\hline CB_05, CB_06, CB_07 & Finishing and/or ground layer & Leaf and putto & Casa Cantoni, Cabbio (CH) & MALDI-TOF \\
\hline SUHE 002 & Stucco finishing layer & Eagle's head & Heissler's study, Uherčice Castle (CZ) & TA, MALDI-TOF \\
\hline JUHE 001 & Stucco ground mortar & Eagle's head & Heissler's study, Uherčice Castle (CZ) & TA, MALDI-TOF \\
\hline SUHE 003 & Stucco finishing layer & Flower bud & Angel's corridor Uherčice Castle (CZ) & $\begin{array}{l}\text { PLM, SEM-EDS, TA, } \\
\text { MALDI-TOF }\end{array}$ \\
\hline JUHE 002 & Stucco ground mortar & Flower bud & Angel's corridor, Uherčice Castle (CZ) & $\begin{array}{l}\text { PLM, SEM-EDS, TA, } \\
\text { MALDI-TOF }\end{array}$ \\
\hline SUHE 001 & Finishing layer (stucco layer) & Wall render & Gate corridor-remains of stuccos & PLM, SEM-EDS, TA, \\
\hline
\end{tabular}


Table 1. Cont.

\begin{tabular}{cccc}
\hline Sample Id & Element & Position & Case Study \\
\hline HH_01 & Stucco stratigraphy & $\begin{array}{c}\text { Large angel to the } \\
\text { left of the main altar, } \\
\text { the wing }\end{array}$ & The Holy Hill Church, Olomouc (CZ) \\
HH_02 & Stucco stratigraphy & $\begin{array}{c}\text { Large angel to the } \\
\text { left of the main altar, } \\
\text { the wing }\end{array}$ & The Holy Hill Church, Olomouc (CZ) \\
HH_03 & Stucco stratigraphy & $\begin{array}{c}\text { Large angel to the } \\
\text { left of the main altar, } \\
\text { the wing }\end{array}$ & The Holy Hill Church, Olomouc (CZ) \\
\hline
\end{tabular}

The choice of representative samples of the different decorative cycles was made thanks to careful macroscopic observations in situ, together with art historians and conservators-restorers, in order to have comparable results, limiting the number and cost of the analyses. The selected analytical techniques are based on well-established methodologies aimed at characterizing the composition of the stucco [15-17]. Petrographic analyses by polarized light microscopy (PLM) offer broad insights into the mineralogical composition, texture, and application techniques. A rapid differentiation of binders (lime, Mg lime, and gypsum) is provided by FT-IR (Fourier-transform infrared spectroscopy). Other important information concerning the proportions of the mixed binders was acquired by TA (thermal analyses) of powdered samples. Microstructure and elemental composition were also studied by SEM-EDS (scanning electron microscopy with an energy-dispersive system) on some selected samples. The aforementioned techniques do not provide conclusive information on organic addition [18] and thus MALDI-TOF (matrix-assisted laser desorption/ionization-time of flight) was also used to evaluate organic addition on the basis of proteins. Internal structures were investigated only by visual observation.

Two different petrographic microscopes (Zeiss Axioskop 40/Olympus BX53M) coupled with digital cameras (Axiocam/Olympus DP27) were used to document the thin sections. Images were taken using the AxioCam 4.5 software/Olympus Stream.

ATR-FT-IR (attenuated total reflectance FT-IR) was performed with a Perkin Elmer UATR (single reflection diamond) spectrometer on powdered samples. The instrument uses a MIR source, a diamond crystal, an OptKBr beam-splitter, and an LiTa03-based detector. Spectra were acquired within the $4000-400 \mathrm{~cm}^{-1}$ range at $4 \mathrm{~cm}^{-1}$ resolutions and with 32 scans.

Tescan MIRA II LMU SEM-EDS (Bruker AXS) was used for characterization of the composition of binder and aggregate on polished thin sections. The SEM-EDS measuring conditions were as follows: the electron accelerating voltage was $15 \mathrm{kV}$. The thin sections were carbon-coated and observed in back-scattered electron mode (BSE).

The purged samples were gently crushed, and the material obtained was passed through a $63 \mu \mathrm{m}$ sieve. The fraction below $63 \mu \mathrm{m}$ was used further for the analyses. An SDT Q600 instrument (TA Instruments) was used to measure thermal behavior between $25^{\circ} \mathrm{C}$ and $1000^{\circ} \mathrm{C}$, for which a sample of approximately $10 \mathrm{mg}$ was heated at the rate of $20^{\circ} \mathrm{C} / \mathrm{min}$ in air and/or in a nitrogen atmosphere.

The presence of proteins derived from potential organic additives was verified by mass spectrometry on the principle of MALDI-TOF. To verify the presence of proteins, samples were cleaved by trypsin for $2 \mathrm{~h}$ then re-cleaned and thickened on a reverse basis C18 (Zip Tip). The analysis was done by nano-liquid chromatography with an ESI-Q-TOF MaxisImpact mass spectrometer. Proteins were identified by the Mascot 2.2.04 software in databases SwissProt, NCBInr, and MS/MS. The databases contain proteins ranging from microorganisms to mammal proteins. This method did not enable the identification of other organic compounds (oils, saccharides, or DNA) [19]. It is suitable for analyzing proteins in small concentrations of about $0.01 \%$ [20]. 


\section{Results}

3.1. Stucco Technique and Composition

3.1.1. Uherčice Castle, 1692-1696 (CZ)

Altogether five different samples of mortars were characterized in detail. Both highrelief decorations, the eagle's head and the flower bud, were similar in their structure. The main body was made with a ground layer mortar that was a mixture of lime, gypsum, and aggregate that was densely packed. Its color was light beige. On top of it was a whitish finishing layer composed of lime and fine aggregate of varying thickness reaching from almost zero up to more than one $\mathrm{cm}$.

The study of the flower bud mortars by PLM-see Figure 5-revealed that the ground mortar has a more heterogeneous aggregate (quartz, feldspars, muscovite, apatite, and limestone), with a typical size from 0.2 to $0.6 \mathrm{~mm}$, but grains up to $2.2 \mathrm{~mm}$ can also be found, compared to the mortar of the finishing layer, where the aggregate is predominantly composed of well-sorted quartz and muscovite grains with a typical size from 0.2 to $0.5 \mathrm{~mm}$. The elongated muscovite grains can even be up to $1 \mathrm{~mm}$ long. In both samples the grains are angular or semi-angular; some have sharp edges as a result of crushing. The binding matrix appears different in each of these samples. The ground mortar has a darker shade of brown and apart from lime it also contains gypsum. It is coarser and also more heterogeneous than the finishing layer. Binder-related particles (BRP) [21]—lime lumps sensu stricto which have rounded edges and are well-merged with the binding matrix - are relatively common in both mortars. They are rather compact, without too many cracks or frequent defects. No calcium sulphate (gypsum, anhydrite) particles or half-burnt lime particles were found in the thin sections. The ratio between binder and aggregate was estimated to be $1.5: 1$ for both mortars. Two separate clusters that had a slightly different binding matrix from the rest of the sample were found in the ground mortar; see Figure 5a.

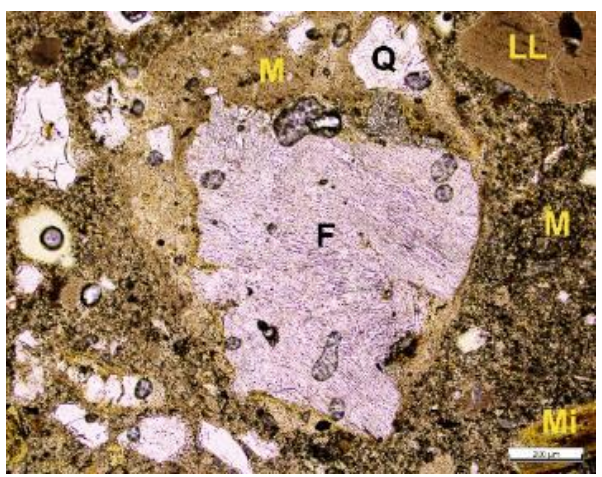

(a)

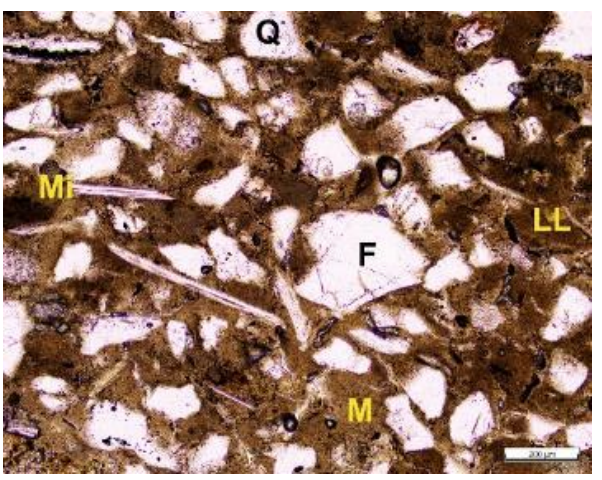

(b)

Figure 5. Photomicrographs of the ground mortar (JUHE 2): (a) detail of a putto stucco decoration of the fireplace; (b) the close-up image shows the structure. It is made of two superimposed layers of mortar, a ground layer and a finishing layer. Inside, the internal wooden structure is visible. $\mathrm{LL}=$ lime lump, $\mathrm{M}=$ binding matrix, $\mathrm{Mi}=$ micas .

The SEM-EDS analysis confirmed the petrographic characterization and also made it possible to examine the composition of the binding matrix and the binder-related particles; see Figure 6 and Table 2. The binding matrix of the ground mortar JUHE 2 was made of calcitic lime with a minor content of magnesium. The content of $\mathrm{SiO}_{2}$ around 8 to $10 \mathrm{wt}$. \% suggests the presence of some impurities and possibly also hydraulic phases in the lime binder. The lime lump and the limestone particles present in the image are, however, quite pure high-calcium materials. The binding matrix also contains $\mathrm{SO}_{3}$, which relates to gypsum, present in the binding system. In comparison, the binder-related particles and the binding matrix of the finishing stucco layers (SUHE 3 and also SUHE 1) have quite a high content of $\mathrm{CaO}$, suggesting the use of air lime as the main and sole binder. 


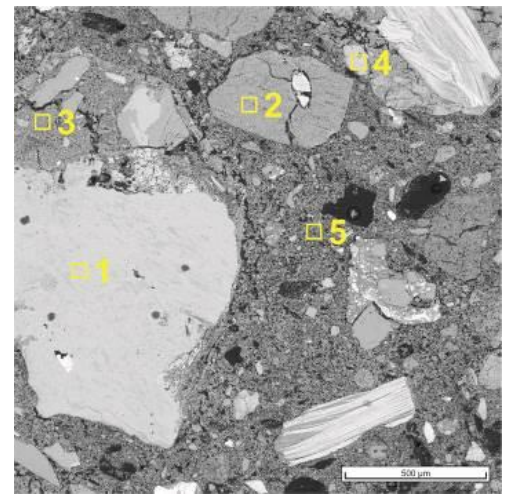

(a)

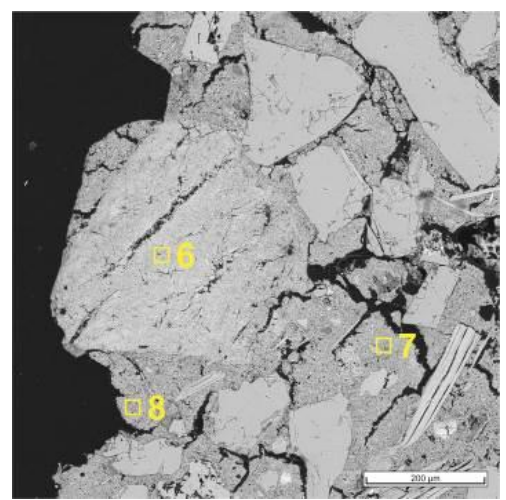

(b)

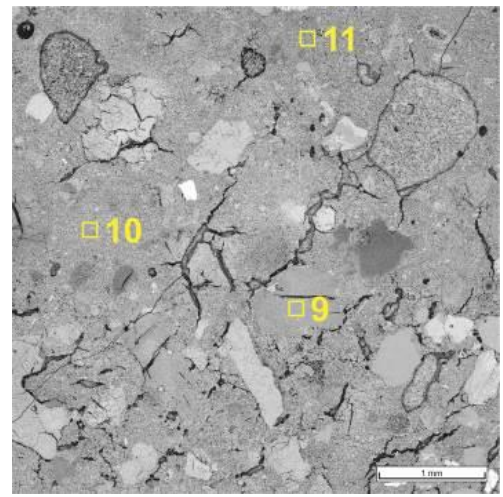

(c)

Figure 6. SEM BSE scans with positions that were analyzed: (a) ground mortar (JUHE 2), (b) the finishing layer (SUHE 3) of the flower bud, and (c) the wall render surface (stucco) layer (SUHE 1).

Table 2. Composition of the selected areas based on SEM-EDS analysis. Quantified weight percentage of the main compounds normalized to $100 \%$. F-feldspar, LL—lime lump, M-binding matrix, L-limestone (marble), n. d.—not detected.

\begin{tabular}{|c|c|c|c|c|c|c|c|c|c|c|c|c|}
\hline & \multicolumn{4}{|c|}{ JUHE 2} & \multicolumn{4}{|c|}{ SUHE 3} & \multicolumn{4}{|c|}{ SUHE 1} \\
\hline & $\mathrm{F}(1)$ & LL (2) & M (3) & L (4) & M (5) & LL (6) & $\mathrm{M}(7)$ & M (8) & LL (9) & LL (10) & M (11) & M (12) \\
\hline $\mathrm{CaO}$ & 0.33 & 97.38 & 85.1 & 97.5 & 78.15 & 96.94 & 91.15 & 97.88 & 93.92 & 94.29 & 90.92 & 93.78 \\
\hline $\mathrm{SiO}_{2}$ & 59.2 & 0.5 & 8.11 & 0.29 & 10.05 & 0.53 & 3.36 & 0.52 & 1.06 & 0.36 & 2.12 & 1.67 \\
\hline $\mathrm{Al}_{2} \mathrm{O}_{3}$ & 23.81 & 0.06 & 1.93 & 0.18 & 3.19 & 0.22 & 1.82 & 0.12 & 0.38 & 0.04 & 0.48 & 0.38 \\
\hline $\mathrm{MgO}$ & 0.66 & 1.01 & 1.67 & 1.86 & 1.15 & 1.27 & 1.57 & 0.86 & 3.78 & 4.13 & 4.76 & 2.98 \\
\hline $\mathrm{Na}_{2} \mathrm{O}$ & 0.23 & 0.2 & 0.14 & 0.1 & 0.53 & 0.44 & 0.59 & 0.17 & 0.31 & 0.08 & 0.67 & 0.19 \\
\hline $\mathrm{K}_{2} \mathrm{O}$ & 15.45 & 0.01 & 0.25 & 0.07 & 0.56 & 0.14 & 0.32 & 0.15 & 0.15 & 0.07 & 0.1 & n. d. \\
\hline $\mathrm{SO}_{3}$ & 0.01 & 0.65 & 1.11 & n. d. & 4.1 & 0.16 & 0.46 & 0.19 & 0.33 & 0.58 & 0.42 & 0.61 \\
\hline $\mathrm{FeO}$ & 0.32 & 0.05 & 1.55 & n. d. & 2.21 & 0.23 & 0.51 & 0.1 & n. d. & 0.16 & 0.2 & 0.11 \\
\hline $\mathrm{MnO}$ & 0.01 & 0.15 & 0.13 & 0.01 & 0.06 & 0.07 & 0.24 & n. d. & 0.07 & 0.29 & 0.34 & 0.27 \\
\hline Total & 100.02 & 100.01 & 99.99 & 100.01 & 100 & 100 & 100.02 & 99.99 & 100 & 100 & 100.01 & 99.99 \\
\hline
\end{tabular}

The TA confirmed the presence of gypsum in the samples of the ground mortars of the flower bud and the eagle's head (JUHE 1 and 2); see Figure 7 and Table 3. The binder of the ground mortar of the flower bud contains as much lime as gypsum; the ratio is approximately 1:1. The ratio also seems to vary and in the case of the eagle, some gypsum is also present in the stucco finishing layer. On the contrary, no gypsum seems to have been added to the stucco finishing layers of the flower bud and the wall render.

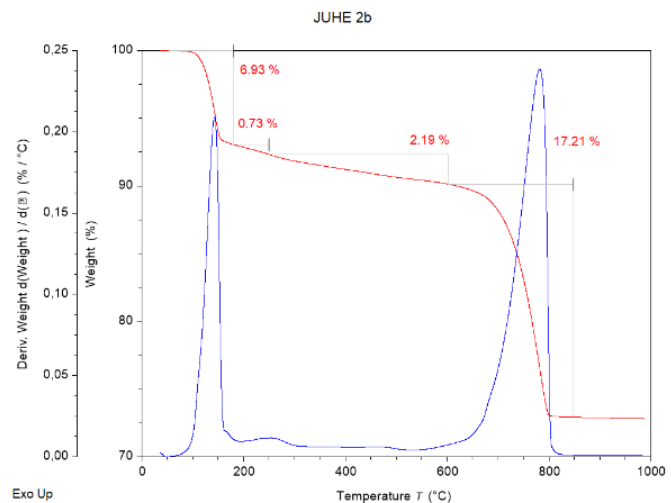

(a)

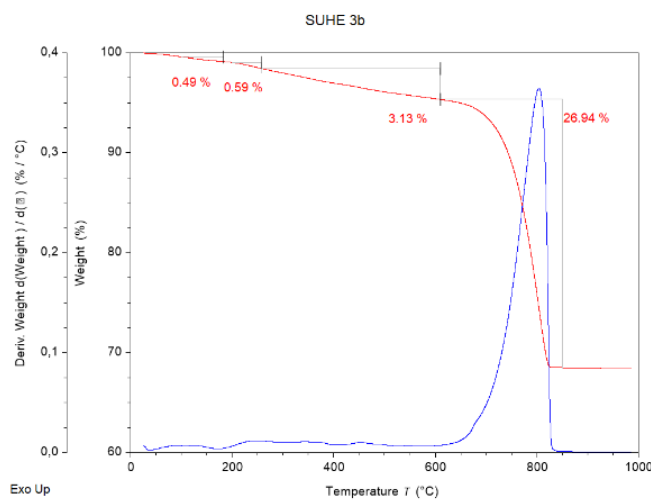

(b)

Figure 7. Weight loss and its derivation of (a) ground mortar sample JUHE2 and (b) finishing layer sample SUHE 1 of the flower bud stucco piece. 
Table 3. Thermal analysis—weight loss of the samples in \% and corresponding quantified proportions of calcium sulphate dihydrate and calcium carbonate. Dehydration of calcium sulphate dihydrate (gypsum) was considered in the temperature range from $100^{\circ} \mathrm{C}$ to $180^{\circ} \mathrm{C}$; decomposition of calcium carbonate (lime) was in the temperature range from $600^{\circ} \mathrm{C}$ to $850^{\circ} \mathrm{C}$.

\begin{tabular}{cccccc}
\hline & $\mathbf{1 0 0 - 1 8 0}{ }^{\circ} \mathbf{C}$ & $\mathbf{1 8 0 - 6 0 0}{ }^{\circ} \mathbf{C}$ & $\mathbf{6 0 0 - 8 5 0}{ }^{\circ} \mathbf{C}$ & $\mathbf{C a C O}_{\mathbf{3}}$ & $\mathbf{C a S O}_{\mathbf{4}} \mathbf{2} \mathbf{H}_{\mathbf{2}} \mathbf{O}$ \\
\hline SUHE 1b & 0.41 & 4.62 & 37.42 & 85.0 & 0.0 \\
SUHE 2b & 0.90 & 4.40 & 32.40 & 73.6 & 4.3 \\
SUHE 3b & 0.49 & 3.72 & 26.94 & 61.2 & 0.0 \\
JUHE 1b & 4.10 & 3.20 & 24.30 & 55.2 & 19.5 \\
JUHE 2b & 6.93 & 2.92 & 17.21 & 39.1 & 33.0 \\
\hline
\end{tabular}

The mass spectrometry on the MALDI-TOF principle qualitatively determined the presence of collagen in the samples of stucco finishing layers SUHE 1 and 2 only. Collagen alpha-1 and -2 chains matched the accessions of CO1A1 BOVIN, CO1A2_BOVIN and CO1A2_MOUSE six, four, and two times in both samples, respectively. There were also two matches of alpha S1-casein and beta-casein milk proteins with the accessions of CASA1_BOVIN and CASB-BOVIN.

\subsubsection{The Holy Hill Church near Olomouc (CZ), 1722-1731}

The three Holy Hill samples showed a very similar stratigraphy: the inner ground layer is composed of a lime-based binder with a lower gypsum content. The ratio between binder and aggregate is visually estimated under the microscope as 2:1. The aggregate has a homogeneous distribution and low sorting, with a fine to coarse sand grain size. The mineralogical composition is mostly silicate, with quartz and fragments of reddish silicate rocks with a high iron content, plagioclase, feldspar, and fragments of magmatic rock and micas. Fragments of bricks are frequent enough to suggest a voluntary addition, while fragments of wood are rare (Figure 8a). The finishing layer has a micritic lime binder with a homogeneous light beige color and well-sorted sand with a fine and very fine grain size. The composition of the sand is almost exclusively of quartz, plagioclase, and feldspar. On the other hand, fragments of magmatic rock and micas are scarce (Figure $8 b$ ). The presence of calcite and quartz in the finishing layer is confirmed by the FT-IR results (Figure 9).

It is noteworthy that the finishing layer is coated with a preparatory layer for gilding or false gilding (Figure 8c), consisting of animal glue and gypsum, covered with a very thin red ochre layer containing $\mathrm{Fe}, \mathrm{Al}$, and $\mathrm{Si}$. The presence of gypsum is confirmed by the SEM-EDS results, while Au was not identified. Subsequent layers can be attributed to more recent decorative phases (Figure 10 and Table 4). Therefore, it can be assumed that these stuccos were originally designed to have a golden appearance.

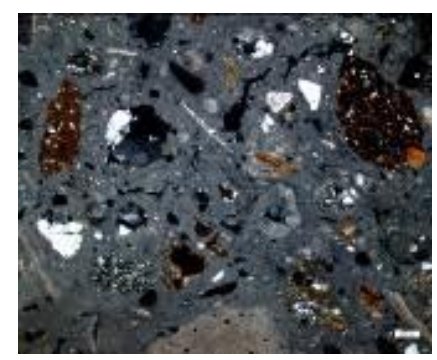

(a)

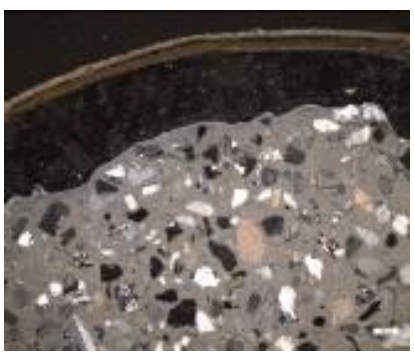

(b)

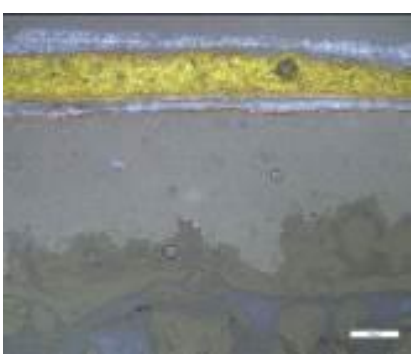

(c)

Figure 8. Photomicrograph of the thin sections, transmitted light, and crossed polars: (a) the ground layer; the binder is composed of gypsum and lime, and cocciopesto additions are visible; (b) the finishing layer made of lime binder and silicate fine sand; and (c) the decorative layer with the preparation for the gilding. 


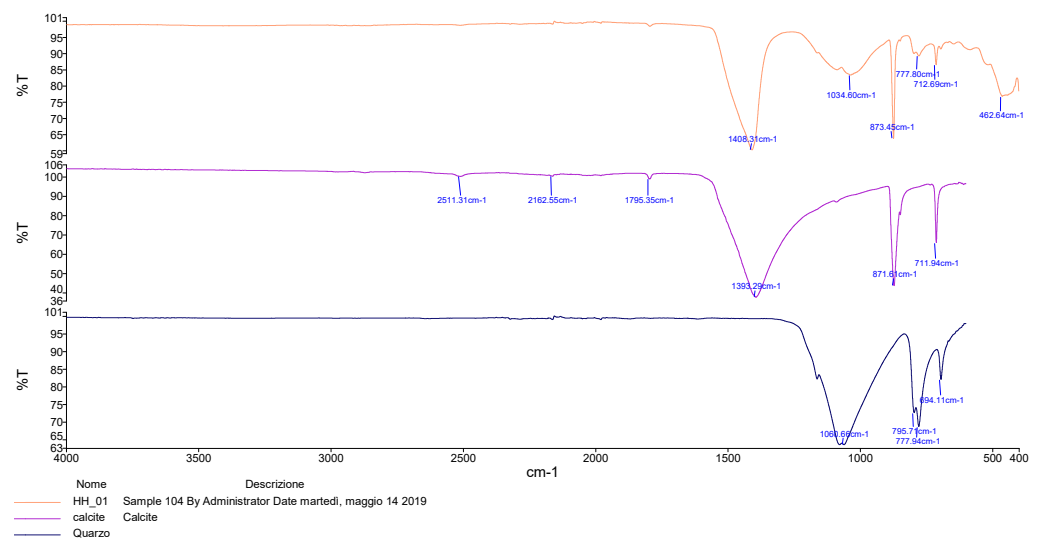

Figure 9. ATR-FT-IR spectra of the finishing layer of the sample HH_1. There is a large and strong band around $1403-1420 \mathrm{~cm}^{-1}$ as a result of the $\mathrm{CaO}$ stretching mode of the carbonate functional group together with a sharp band at $872 \mathrm{~cm}^{-1}$ of the bending mode and at $712 \mathrm{~cm}^{-1}$. The reference spectra of calcite (violet) and quartz (black) are also shown for comparison.

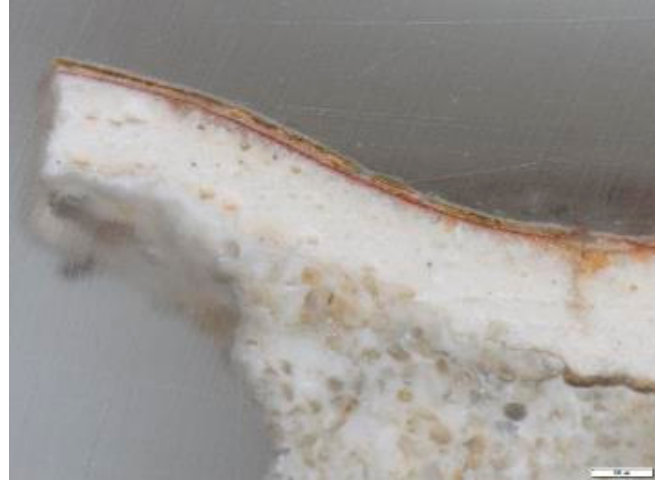

(a)

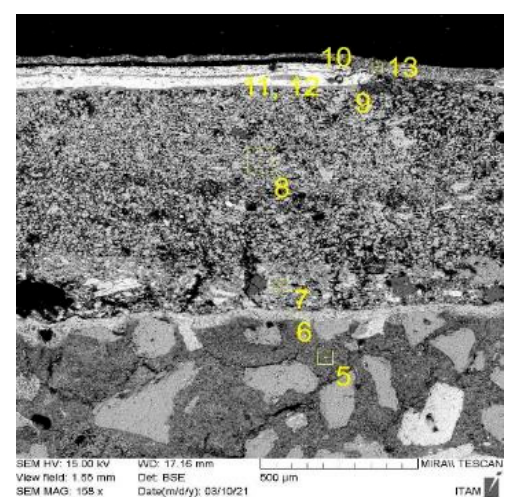

(b)

Figure 10. Sample HH1: (a) stratigraphy showing the finishing layer and the whitewash (lime putty) with the preparation for gilding; (b) images from where the SEM-EDS measurement points in Table 4 were taken.

Table 4. Composition of the selected areas of sample HH1 based on SEM-EDS analysis. Quantified weight percentage of the main compounds normalized to $100 \%$. M-binding matrix, GL—gypsum-based layer, PL—paint layer, (n)—number of the measurement point, n. d.-not detected.

\begin{tabular}{ccccccccc}
\hline & M (5) & GL (6) & GL (8) & PL (9) & PL (10) & PL (11) & PL (12) & PL (13) \\
\hline $\mathrm{CaO}$ & 91.58 & 47.43 & 48.22 & 1.77 & 2.41 & 8.91 & 3.42 & 49.57 \\
$\mathrm{SiO}_{2}$ & 3.94 & n. d. & 1.38 & 35.76 & 0.14 & 2.23 & 0.71 & 10.25 \\
$\mathrm{Al}_{2} \mathrm{O}_{3}$ & 1.38 & n. d. & 0.41 & 36.92 & 0.28 & 17.74 & 14.14 & 8.12 \\
$\mathrm{MgO}$ & 0.83 & n. d. & 0.67 & 0.63 & n. d. & 0.37 & 0.07 & n. d. \\
$\mathrm{Na}_{2} \mathrm{O}$ & 0.37 & n. d. & 0.43 & 1.68 & n. d. & 1.71 & 1.05 & n. d. \\
$\mathrm{K}_{2} \mathrm{O}$ & n. d. & n. d. & n. d. & 0.33 & n. d. & n. d. & n. d. & 0.47 \\
$\mathrm{SO}_{3}$ & 1.2 & 52.57 & 48.9 & 1.45 & 8.14 & n. d. & n. d. & 7.85 \\
$\mathrm{Cl}$ & 0.69 & n. d. & n. d. & n. d. & n. d. & n. d. & n. d. & 0.50 \\
$\mathrm{FeO}$ & n. d. & n. d. & n.d. & 15.9 & n. d. & n. d. & n. d. & n. d. \\
$\mathrm{TiO}_{2}$ & n. d. & n. d. & n. d. & 1.9 & n. d. & n. d. & n. d. & n. d. \\
$\mathrm{BaO}$ & n. d. & n. d. & n. d. & n. d. & 13.05 & n. d. & n. d. & n. d. \\
$\mathrm{PbO}$ & n. d. & n. d. & n. d. & n. d. & n. d. & 57.61 & 58.86 & n. d. \\
$\mathrm{Cr} \mathrm{O}_{3}$ & n. d. & n. d. & n. d. & n. d. & n. d. & 11.42 & 21.76 & n. d. \\
$\mathrm{ZnO}$ & n. d. & n. d. & n. d. & 3.65 & 75.98 & n. d. & n. d. & 23.25 \\
$\mathrm{Total}$ & 99.99 & 100 & 100.01 & 99.99 & 100 & 99.99 & 100.01 & 100.01 \\
\hline
\end{tabular}




\subsubsection{Church of San Giovanni Evangelista, Morbio Superiore (CH), 1701}

Microscopically, these bas-relief stuccoes are composed only of a finishing layer, made of a solely lime binder with frequent lime lumps sensu strictu. On the other hand, the cornice, characterized by higher relief, is made of two layers. The ground layer, together with the lime binder, also contains gypsum and aggregate (Figure 11).

The absence of proteinaceous addition was confirmed by MALDI-TOF analysis of the samples SG7, SG8, SG9, and SG10. In the sample SG7 animal or human hair could have been added. It is not possible to exclude the possibility that this could have been a secondary contamination.

\subsubsection{Casa Cantoni, Cabbio (CH), Early 18th Century (?)}

The ground layer is composed of $\mathrm{Mg}$ lime binder and gypsum. BRP of lime and gypsum are frequently present. The proportion between binder and aggregate is $1: 1$ by volume. The aggregate has a moderate sorting, with prevailing coarse and very coarse grain size. The composition is made up of calciferous limestone and fragments of metamorphic silicate rocks. The porosity has an irregular shape and elongated shrinkage cracks are also visible (Figure 12a). The finishing layer has a homogeneous isotropic dark and dense binder, with lime lumps. The use of aggregate is very sporadic and only a few fragments of calcite and rare quartz are observed (Figure 12b).

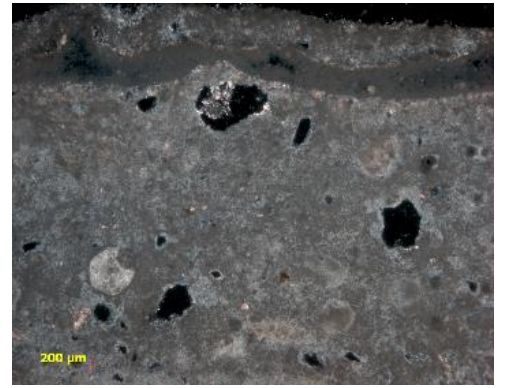

(a)

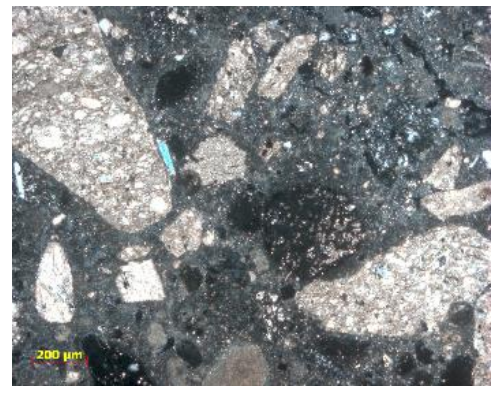

(b)

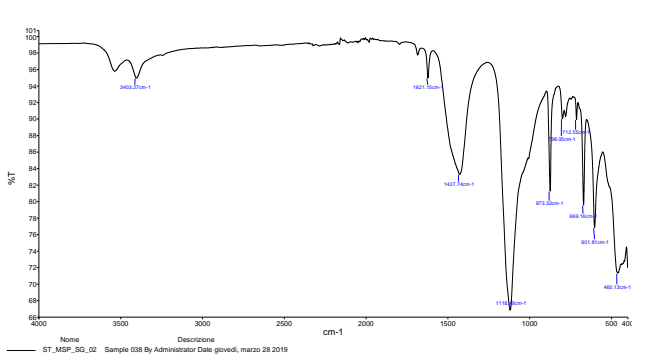

(c)

Figure 11. (a,b)-Photomicrographs of the thin sections, transmitted light, crossed polars, of samples: (a) MSP_SG 01 (finishing layer), made only of lime putty without aggregate, and (b) MSP_SG 02 (ground layer), made of lime and gypsum as a binder and selciferous limestone as aggregate; (c) FT-IR spectrum of the sample MSP_SG 02, showing the presence of lime, gypsum, and a silicate component.

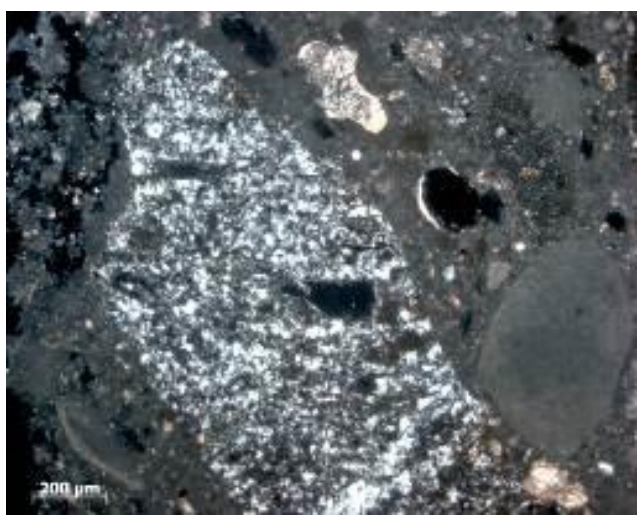

(a)

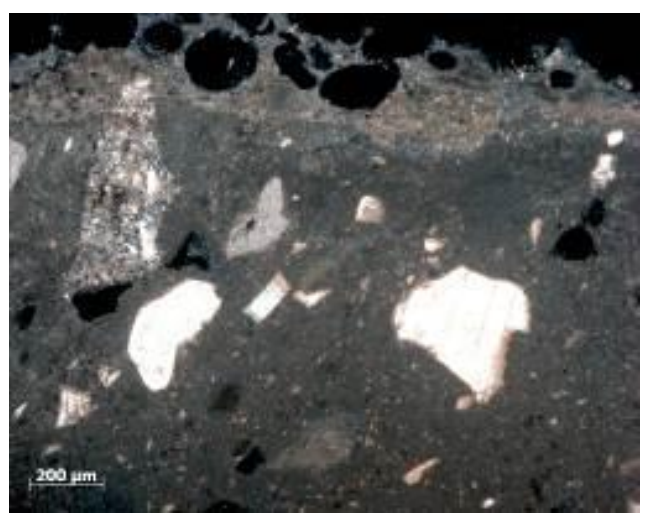

(b)

Figure 12. Photomicrograph of the thin sections, transmitted light, and crossed polars: (a) sample CB_CCC 01, ground layer with a coarse calciferous limestone fragment in the center and one lime lump on the right; (b) sample CB_CCC 03, stucco layer made of lime putty with sporadic fine fragments of calcite. 
The MALDI_TOF results show that no proteins were used as additives for the samples CB6 and CB7, but casein (milk proteins) was found in the sample CB5. There were two matches of Beta-casein with CASB_BOVIN accession and one match of alpha S1-, S2and kappa-casein with CASA1_BOVIN, CASA2_BOVIN and CASK_BOVIN accessions, respectively.

\subsection{Material Resources (Lime, Gypsum, Sand, and Additives) \\ 3.2.1. Ticino $(\mathrm{CH})$}

The study of the potential sources of the supply of raw materials was carried out through a comparison between the geology of the area and the petrography of the stucco mortar. For the realization of the stuccoes that were analyzed, lime and gypsum were used as binders, and calcite/marble fragments or river sand as aggregate. Lime in Ticino was historically obtained from the firing of dolomitic limestones, which are characteristic of the area [22], and therefore a magnesium component is often found, even if in variable percentages $[23,24]$. The closest gypsum quarries are located on Lake Como, at Nobiallo and Limonta (Italy), or at Melide, Rogno-Campione, and Meride, in Switzerland [25]. The petrographic study of the aggregate makes it possible to identify the supply sand as very close to the case studies examined, since the sandy deposits of the lower Ticino are characterized by flint limestone and silicate sands (subordinately).

\subsubsection{Moravia (CZ)}

In order to gain information about the raw materials used in Uherčice Castle, the stucco samples were compared with locally occurring marble. A former quarry is located directly on the estate, approximately $500 \mathrm{~m}$ east of the castle, and there was also a lime kiln. The quarry is abandoned nowadays and is gradually being backfilled with waste. The local marble has a variable quality across an open quarry face $100 \mathrm{~m}$ long and about $15 \mathrm{~m}$ high. It is light to dark grey, fine to medium coarse crystalline marble. It is heterogeneous with characteristic bands. The main component is calcite, with some dolomitized parts. The non-carbonate impurities are actinolite, biotite, talc, diopside, quartz, and chlorite [26]. The closest gypsum deposits to Uherčice are located about $150 \mathrm{~km}$ south, in the northeastern part of the Northern Limestone Alps of the Permian Triassic periods in Austria. The second nearest deposits are located about $300 \mathrm{~km}$ northeast, on the Czech-Polish border in the Opava Basin, which is a part of the Carpathian Foredeep, and the local gypsums are from the Neogene period. A distinction between these localities is possible on the basis of isotope analysis of the $\delta^{34} \mathrm{~S}$ and ${ }^{84} \mathrm{Sr} /{ }^{86} \mathrm{Sr}$ content [27]. The mineralogy of the aggregate corresponds to the local geology. Metamorphic rock types such as granulite, amphibolite, and gneisses prevail in the region of Uherčice. These rocks are rich in quartz, feldspars, and micas, and contain heterogeneous sharp-edged grains, the minerals typically found in the layers of stuccoes. The aggregate is of alluvial origin (weathered in situ), and there are several places nearby that could have been its source.

The potential raw material for lime used in the Holy Hill stuccoes can be localized south of Olomouc, approximately $12 \mathrm{~km}$ from the church. In this area, outcrops of Upper Devonian Hněvotín limestone (Líšeň formation) occurs [28]. This grey-colored limestone type is characterized by a dolomitic admixture and the presence of thin layers composed of calcareous shales [29]. The Holy Hill Church is about $80 \mathrm{~km}$ from Opava, the only natural source of gypsum in the Czech Republic. An analytical provenance study has not been carried out yet, but the relative proximity and the uniqueness of the source suggests the Opava Basin as a highly probable source area. Gypsum originating from Opava is mentioned in the case of supplies for stucco works planned at Plumlov Castle at the end of the 17 th century [30].

The mineralogical composition and character of the aggregate in the Holy Hill stuccoes indicate an alluvial origin (weathered material transported and deposited). The aggregate used is a low-sorted river sediment which was transported from areas with the occurrence 
of magmatic and metamorphic rocks (west and northwest of Olomouc). These deposits can be found nearby in the floodplain of the Morava River.

\section{Discussion}

\subsection{Stucco Layers and Their Composition}

All the stucco pieces taken from Uherčice Castle that were studied were made as a layered system, which was also reinforced or anchored to the substrate depending on their shape and position (Table 5). The inner, core part (ground layer) was made of lime, gypsum, and aggregate. The finishing layer was made of lime and aggregate. If gypsum was added it followed a specific reason, e.g., to ensure a faster initial set, as in the case of the narrow neck of an eagle. Both layers have a very good mutual bond and seem to have been applied wet-on-wet. In terms of composition, the main difference between these two layers is the presence of gypsum and also the selection of raw materials. The lime was most probably from the local production owned by the estate and thus the same composition could be expected. However, the analyses showed that for the surface finishes a very pure high-calcium lime was used, which was in contrast to the less pure lime binder used in the ground mortar. This documents the deliberate preference provided by the selection and processing of raw materials. It is possible that the selection, based on quality, was made directly in the quarry or later on during the calcination and further production and preparation processes. The lime in the mortar of the ground layer was more heterogeneous and made from less pure limestone, and it possibly also contained some hydraulic phases. Similarly, the chosen aggregate was more heterogeneous in composition and size in the ground mortar than in the stucco finishing layer. In both cases, the shape of the grains was semi-angular to angular and some particles were clearly a result of mechanical crushing. The sand was of local origin, with dominant fractions of quartz and feldspars; the angularity of the grains suggests a short transport by streams or rivers, if any. The sand could have been dug from alluvial layers, as the clay particles present in the ground mortar would indicate. The sand used in the stucco finishing layer was composed mostly of quartz and a relatively large amount of muscovite, which again confirms the attention paid to the selection and sand preparation process. The size of the sieves used can be estimated at $0.5 \mathrm{~mm}$ for the stucco finishing layer and around $2 \mathrm{~mm}$ for the ground mortar. The gypsum used was probably very finely ground, as no larger particles were found in the thin sections by means of PLM. The volumetric binder to aggregate ratio of the ground mortar and the stucco finishing layer was estimated as 1.5:1. The ratio between lime and gypsum is about 1:1 by weight, but it is estimated that the gypsum content varied from case to case, depending on the application. The light beige color of the core mortar is due to the aggregate, which contained fine clay particles, the less pure lime, as mentioned above, and possibly also to the secondary use of crushed older mortar. In the case of the stucco layer on the wall render (SUHE 1), only slaked lime with no added sand was used. The layer, about $0.4 \mathrm{~mm}$ thick, contained only natural impurities that corresponded to those present in the local marble.

Collagen was found to be present in the finishing layer of the eagle's head stucco but not in the ground mortar. This was quite surprising, as collagen, or animal glue, is a common additive that modifies and slows down the setting of gypsum and therefore its presence in this context was expected. Further analytical studies are needed to explain this.

The Ticino stuccoes attributed to Fontana were made in two layers: an internal layer for creating the shape directly applied to the anchoring system and a finishing layer. This latter layer is further refined with whitewash. For the low reliefs of the San Giovanni Church, nail anchors are used sporadically, because of the low projection. The particular use of wooden branches for the puttino's leg of the Cabbio fireplace is noteworthy.

In all the samples that were analyzed the ground layer is composed of lime, gypsum, and aggregate. On top of it, a finishing layer made of lime with frequent lime lumps and very few fine aggregates was observed. Similarly to Uherčice Castle and to other stucco works in Ticino, the compositional difference between the two layers of stucco emerges in 
the presence of gypsum and in the selection of raw materials. Sand from a nearby river was used for the ground mortars, while for the finishing, the homogeneous composition (calcite and quartz) with an angular shape suggests mechanical crushing and thus the use of quarry material. The sand of a nearby watercourse was used instead for the internal ground mortars, because the composition reflects that of the local geological materials, as emerges from the comparison between the stucco sand and the local geology. For the lower Ticino areas such as Morbio Superiore and Cabbio, silicate and carbonate sands are available in the rivers, with calciferous limestone and a lesser amount of metamorphic rock fragments such as gneiss or schists. The variable particle size from fine to very coarse suggests little or no sorting of the aggregate. A proteinaceous component derived from casein or milk was found only in one case, in the finishing layer of a small leaf of the chimney. Casein can be used in order to delay the carbonation of lime and to modify the workability by increasing the plasticity of the stucco paste. The latter was the most probable intention.

These results (Table 5) show that the mortars used in the case studies that were analyzed are made with the same components as those chosen by other authors in the same period and area. The main difference is the bas-relief technique used by Fontana and the absence of aggregate in the finishing layer. This characteristic of the finishing layer has also been observed in some works by other authors, such as the Casella and the Colomba family, while the Silva family, Giovan Battista Barberini, and Isidoro Bianchi also added marble powder [15,24]. The use of casein or milk was also found in other stucco artworks [24].

Table 5. Summary of results: the composition of the layers of the stucco works in the different case studies is compared according to the analytical findings.

\begin{tabular}{|c|c|c|c|c|c|}
\hline Case Study & $\begin{array}{c}\text { Type of Stucco } \\
\text { Work }\end{array}$ & Stucco Layers & Binder & Aggregate & Additives \\
\hline $\begin{array}{l}\text { Church of San Giovanni } \\
\text { Evangelista }(\mathrm{CH})\end{array}$ & Bas-relief & Finishing & $\begin{array}{c}\mathrm{Mg} \text { lime } \\
\text { (frequent lime lumps) }\end{array}$ & No aggregate & $\begin{array}{l}\text { Animal } \\
\text { or human hair }\end{array}$ \\
\hline $\begin{array}{c}\text { Church of San Giovanni } \\
\text { Evangelista }(\mathrm{CH})\end{array}$ & Cornice & Ground layer & $\begin{array}{l}\text { Mg lime } \\
\text { Gypsum }\end{array}$ & $\begin{array}{l}\text { Not-sorted calciferous } \\
\text { limestone, silicate rock } \\
\text { fragments }\end{array}$ & nd \\
\hline Casa Cantoni, Cabbio $(\mathrm{CH})$ & High relief & Finishing layer & $\begin{array}{c}\mathrm{Mg} \text { lime } \\
\text { (dense and isotropic) }\end{array}$ & $\begin{array}{l}\text { Sporadic calcite and quartz } \\
\text { fragments }\end{array}$ & $\begin{array}{l}\text { Casein (milk protein) } \\
\text { (one sample only) }\end{array}$ \\
\hline Casa Cantoni, Cabbio $(\mathrm{CH})$ & High relief & Ground layer & $\begin{array}{l}\text { Mg lime } \\
\text { Gypsum }\end{array}$ & $\begin{array}{l}\text { Moderate sorting. } \\
\text { Calciferous limestone, } \\
\text { metamorphic rocks }\end{array}$ & nd \\
\hline $\begin{array}{l}\text { Heissler's study, Uherčice } \\
\text { Castle (CZ) }\end{array}$ & High relief & Finishing layer & Lime & $\begin{array}{l}\text { Good sorting. } \\
\text { Quartz and muscovite grains }\end{array}$ & $\begin{array}{c}\text { Collagen, casein } \\
\text { (both in two samples) }\end{array}$ \\
\hline $\begin{array}{l}\text { Heissler's study, Uherčice } \\
\text { Castle (CZ) }\end{array}$ & High relief & Ground layer & Lime and gypsum & $\begin{array}{c}\text { Low sorting. } \\
\text { Quartz, feldspar, muscovite, } \\
\text { apatite, and limestone }\end{array}$ & nd \\
\hline $\begin{array}{l}\text { The Holy Hill Church, } \\
\text { Olomouc (CZ) }\end{array}$ & High relief & Finishing layer & Lime & $\begin{array}{l}\text { Good sorting. } \\
\text { Quartz, plagioclase, and } \\
\text { feldspar }\end{array}$ & nd \\
\hline $\begin{array}{l}\text { The Holy Hill Church, } \\
\text { Olomouc (CZ) }\end{array}$ & High relief & Ground layer & Lime and gypsum & $\begin{array}{c}\text { Low sorting. } \\
\text { Quartz, silicate rock } \\
\text { fragments, plagioclase, } \\
\text { feldspar, and micas. } \\
\text { Brick fragments. }\end{array}$ & nd \\
\hline
\end{tabular}

\subsection{Technology and Processing of Materials}

Lime was produced by the estate of Uherčice and thus all the necessary knowledge and skills were available. Limestone was quarried by hand tools and burnt in flare kilns using wood as fuel. The whole process was performed manually and it comprised a series of steps that allowed separation and selection based on quality (properties) [31]. The purest calcitic lime was used for the stucco surface finishes, as discussed above. The analyses do not allow us to conclude whether the lime was used in the form of a putty or dry slaked powder. However, an interesting point to note is that the lime lumps are rounded and well-integrated in the binding matrix. They also seem not to exceed the size 
of the aggregate. These two points would support a hypothesis that the lime was slaked to powder, sieved, and then used to prepare the mortar. It is also easier to add a finely ground gypsum to a dry mix in amounts according to the piece to be modeled before it is mixed with water. Such a method of preparing mortar would be suitable for work where only small quantities are processed and the mortar has a limited open time for processing. In addition, dry slaked lime allows the preparation of mortars with a very low water content which are needed for modeling stucco pieces. These points related to technologies need to be verified by experiments and further studies of Fontana's work.

The frequent presence of BRP in the Ticinese stucco makes it possible to argue about production technologies. A good knowledge of the combustion process of limestone and gypsum stone is highlighted by the exclusive presence in the stuccoes of BRP sensu strictu, while no underburned grains of limestone or gypsum stone or overburned ones (anhydrite or sintered particles limestone) are observed. In the case studies analyzed, the use of magnesium lime can only be supposed, because specific analyses have not been carried out. Rounded formations attributable to the $\mathrm{Mg}$ phases can be identified in the binder of the stuccoes of the church of San Giovanni.

\section{Conclusions}

This preliminary study aimed to investigate how much the famous Ticino plasterers were able to adapt their modus operandi to the available raw materials and local needs during their working travels across the Alps. An emblematic example was Baldassarre Fontana, who worked with his workshop in various regions of Europe, often hundreds of kilometers apart: in today's Switzerland, Germany, and especially the Czech Republic and Poland. In these regions, he had to fulfil the diverse wishes of his customers, and therefore improvise and adapt in many ways.

All the high-relief stuccoes that were analyzed are made up of different layers. The ground layer is made with lime, gypsum, and unselected sand, with a prevalent percentage of binder compared to the aggregate content in the mortar mix. Although there is only one gypsum outcrop in Moravia or today's Czech Republic, artisans made sure that they could find it even many kilometers away ( $150 \mathrm{~km}$ or possibly even $330 \mathrm{~km}$ ). This observation can indicate how its use was, for many authors, of fundamental importance for the realization of stucco works with a major overhang. If the ground layer appears fairly homogeneous in all the case studies, substantial differences emerge in the realization of the finishing layer. While in the Czech Republic it is a thick layer made of lime with significant quantities of well-selected fine sand, in the stuccoes from Ticino the finishing layer is composed almost exclusively of lime, with a further coat of limewash. This difference in composition cannot be attributed to differences in the raw materials present abroad. The study of more samples will help to better clarify this aspect and the motivation behind it. An important limitation is the few cases of stucco decorations by Fontana in Ticino, which prevents a deeper study of his work in his homeland.

Author Contributions: Conceptualization: M.C., J.V. and J.Z.; investigation: M.C. (study of mortars from CH), J.V. (led the study of mortars from Uherčice Castle, carried out PLM), P.K. (carried out analysis using PLM and SEM-EDS and contributed to the text), and D.F. (analysis using TA); main writing-preparation of original draft, M.C., J.V. and J.Z.; writing the description of the artistic technique: A.F. and G.N.; writing-review and editing, G.J.; funding acquisition: J.Z. All authors have read and agreed to the published version of the manuscript.

Funding: This study was made possible thanks to the funding of OA ITI-ARTECA: Advanced physical-chemical methods of research and protection of cultural and artistic heritage, No.: CZ.02.1.01/0.0/0.0/17_048/0007378. and a project financed by the Czech Ministry of Culture, NAKI DG20P02OVV028.

Institutional Review Board Statement: Not applicable.

Informed Consent Statement: Not applicable. 


\section{Data Availability Statement: Not applicable.}

Acknowledgments: The analysis of organic substances was provided by the laboratory of the University of Chemistry and Technology, Prague, under the leadership of Štěpánka Kučková Hrdličková.

Conflicts of Interest: The authors declare no conflict of interest. The funders had no role in the design of the study, in the collection, analyses, or interpretation of the data, in the writing of the manuscript, or in the decision to publish the results.

\section{References}

1. Damiani Cabrini, L. Le migrazioni d'arte. In Storia Della Svizzera Italiana; Ceschi, R., Ed.; Dal Cinquecento al Settecento: Bellinzona, Switzerland, 2000; pp. 289-312.

2. Sulewska, R.; Smoliński, M. Artyści znad jezior lombardzkich w nowożytnej Europie. Práce Dedykowane Pamięci Profesora Mariusza Karpowicza; Artisti dei laghi lombardi nell'Europa moderna; Studi dedicati alla memoria del Prof. Mariusz Karpowicz, Warszawa; Muzeum Pałacu Króla Jana III w Wilanowie, Instytut Historii Sztuki: Warsaw, Poland, 2015.

3. Zapletalová, J.; Viganò, M. Libro Delli Dinari. Viaggi e Affari di Giovanni Domenico Lucchese, Mastro Stuccatore da Melide all'Europa 1648-1670; Salvioni ed.: Bellinzona, Switzerland, 2021; p. 368.

4. Rampazzi, L.; Rizzo, B.; Colombo, C.; Conti, C.; Realini, M.; Bartolucci, U.; Colombini, M.P.; Spiriti, A.; Facchin, L. The stucco decorations from St. Lorenzo in Laino (Como, Italy): The materials and the techniques employed by the "Magistri Comacini". Anal. Chim. Acta. 2008, 630, 91-100. [CrossRef] [PubMed]

5. Máčelová, L. Baldassare Fontana na Moravě. Ph.D. Thesis, Masaryk University in Brno, Faculty of Arts, Brno, Czechia, 1949.

6. Karpowicz, M. Baldasar Fontana 1661-1733: Un Berniniano Ticinese in Moravia e Polonia; Fondazione Ticino Nostro: Lugano, Switzerland, 1990.

7. Karpowicz, M. Baltazar Fontana, Warszawa, Semper. 1994. Available online: https://polona.pl/item/baltazar-fontana,MTE5 MzEwNw/2/\#info:metadata (accessed on 13 June 2021).

8. Karpowicz, M. Baldassarre Fontana. Addenda et corrigenta, Archivio storico ticinese XXXIV; Archivio Storico Ticinese: Bellinzona, Switzerland, 1997; pp. 239-250.

9. Karpowicz, M. Baldasar Fontana da Chiasso 1661-1733. La Sua Arte in Europa, Convegno Internazionale di Studi; Bibliotheca Hertziana: Chiasso, Switzerland, 2011.

10. Jeřábek, M. Zámek v Uherčicích na přelomu 17. a 18. století. Zprávy Památkového Ústavu v Brně. Bachelor's Thesis, Brno, Czech Republic, 1998; pp. 63-68.

11. Prokop, A. Die Markgrafschaft Mähren in kunstgeschichtlicher Beziehung I-IV; R. Spies: Wien, Austria, 1904.

12. Richter, V. Poznámky k dějinám barokní architektury na Moravě. Volné Směry XXXVII, 1941-1942. pp. 286-296. Available online: https: / /biblio.hiu.cas.cz/records/36b376a0-6f16-4b85-85a3-d0ba09a8a767 (accessed on 13 June 2021).

13. Simona, L. L'arte dello Stucco nel Cantone Ticino, parte II-Il Sottoceneri; Istituto Editoriale Ticinese: Bellinzona, Switzerland, 1949; p. 77.

14. Martinola, G. Inventario Delle Cose d'arte e di Antichità del Distretto di Mendrisio; Edizione dello Stato: Lugano, Switzerland, 1975.

15. Rampazzi, L.; Rizzo, B.; Colombo, C.; Conti, C.; Realini, M.; Bartolucci, U.; Colombini, M.P.; Spiriti, A.; Facchin, L. The Stucco Technique of the Magistri Comacini: The Case Study of Santa Maria Dei Ghirli in Campione D'italia (Como, Italy). Archaeometry 2012, 54, 926-939. [CrossRef]

16. Bartz, W.; Kierczak, J.; Gasior, M.; Zboińska, K. Analytical overview of different Baroque plastering techniques applied in the post-Cistercian abbey in Lubiąż (South-Western Poland). J. Cult. Herit. 2017, 28, 37-47. [CrossRef]

17. Válek, J.; Skružná, O.; Kozlovcev, P.; Frankeová, D.; Mácová, P.; Viani, A.; Kumpová, I. Composition and technology of the 17th century stucco decorations at Červená Lhota Castle in Southern Bohemia. Int. J. Archit. Herit. 2020, 14, 1-16. [CrossRef]

18. Aksamija, A.; Nowik, W.; Lehuédé, P.; Le Hô, A.S.; Bormand, M.; Bouquillon, A. Investigation of organic additives in Italian Renaissance devotion stucco reliefs from French collections. J. Cult. Herit. 2019, 39, 66-81. [CrossRef]

19. Krizova, I.; Schultz, J.; Nemec, I.; Cabala, R.; Hynek, R.; Kuckova, S. Comparison of analytical tools appropriate for identification of proteinaceous additive in historical mortars. Anal. Bioanal. Chem. 2018, 410, 189-200. [CrossRef] [PubMed]

20. Kuckova, S.; Cejnar, P.; Santrucek, J.; Hynek, R. Characterization of proteins in cultural heritage using MALDI-TOF and LC-MS/MS mass spectrometric technique. Phys. Sci. Rev. 2018, 4. [CrossRef]

21. Elsen, J. Microscopy of historic mortars-A review. Cem. Concr. Res. 2006, 36, 1416-1424. [CrossRef]

22. Cavallo, G.; Biondelli, D. The use of magnesian lime in historical mortars in Tessin Canton, Switzerland: Microscopical features and microanalytical evidences. In Proceedings of the VII Congresso Associazione Italiana di Archeometria, Modena, Italy, 22-24 February 2012.

23. Caroselli, M.; Cavallo, G.; Felici, A.; Aliverti, L.; Luppichini, S.; Jean, G.; Nicoli, G. Characterisation of the stucco decorations at the "Sacro Monte di Ossuccio" (16th-17th century), Como, Italy. Int. J. Conserv. Sci. 2016, 7, 857-870.

24. Caroselli, M.; Zumbühl, S.; Cavallo, G.; Radelet, T. Composition and techniques of the Ticinese stucco decorations from the 16th to the 17th century: Results from the analysis of the materials. Herit. Sci. 2020, 8, 1-20. [CrossRef] 
25. Caroselli, M.; Cavallo, G.; Felici, A.; Luppichini, S.; Nicoli, G.; Aliverti, L.; Jean, G. Gypsum in Ticinese stucco artworks of the 16-17th century: Use, characterization, provenance and induced decay phenomena. J. Archaeol. Sci. Rep. 2019, 24, 208-219. [CrossRef]

26. Kozlovcev, P. Influence of the Mineralogical Composition of Raw Material on Phases Formed During the Burning of Hydraulic Lime and Natural Cement. Ph.D. Thesis, Charles University, Prague, Czech Republic, 2018; p. 184.

27. Válek, J.; Skružná, O.; Kozlovcev, P.; Waisserová, J.; Wichterlová, Z.; Maříková-Kubková, J. Podle Starého Vzoru: Rekonstrukce Malt, Sgrafit a Štuků. ÚTAM AV ČR, 2020. Prague. Available online: http://invenio.nusl.cz/record/387718/files/content.csg.pdf (accessed on 13 June 2021).

28. Chlupáč, I.; Brzobohatý, R.; Kovanda, J.; Stráník, Z. Geologická Minulost České Republiky; Academia: Prague, Czech Republic, 2002.

29. Zukalová, V.; Chlupáč, I. Stratigrafická klasifikace nemetamorfovaného devonu moravskoslezské oblasti. Čas. Mineral. Geol. 1982, 27, 225-241.

30. Kühndel, J.; Mathon, J. Plumlovský Zámek a Jeho Knižecí Architect, 3rd ed.; Publikace Městského musea v Prostějově: Celákovice, Slovakia, 1937.

31. Válek, J. Lime Technologies of Historic Buildings. Ústav Teoretické a Aplikované Mechaniky; Akademie věd České republiky (ÚTAM AV ČR): Prague, Czech Republic, 2015. 